\title{
KEGIATAN WORKSHOP UNTUK MENINGKATKAN JUMLAH MAHASISWA PROGRAM STUDI TEKNIK
}

\author{
Carolina $^{1}$, Amandus Jong Tallo ${ }^{2}$ \\ ${ }^{1}$ Jurusan Teknik Arsitektur, Fakultas Teknik, Universitas Agung Podomoro, APL Tower Lt. 5, Jakarta \\ ${ }^{2}$ Jurusan Perencanaan Wilayah Kota, Fakultas Teknik, Universitas Agung Podomoro, APL Tower \\ Lt. 5, Jakarta \\ Email: carolina.setiawan@podomorouniversity.ac.id
}

\begin{abstract}
Abstrak
Minat calon siswa pada program studi teknik di perguruan tinggi swasta dan negeri semakin berkurang. Data menunjukan hanya $14 \%$ mahasiswa yang memilih program studi teknik. Pada lingkup yang lebih kecil, jumlah peminat mahasiswa teknik di salah satu universitas swasta hanya $25 \%$ dibandingkan program studi ilmu sosial. Tujuan dari dilakukannya penelitian ini adalah untuk merumuskan penyebab rendahnya minat calon mahasiswa terhadap program studi teknik sekaligus mencoba untuk menyusun solusi-solusi aplikatif yang sudah dicoba, teori-teori yang relevan, yang dirasa dapat membantu dalam memecahkan masalah. Metode yang digunakan dalam penelitian ini adalah deskriptif kuantitatif. Data yang digunakan berasal dari hasil kuesioner mahasiswa baru dan data-data terkait dengan jumlah mahasiswa baik ditingkat kopertis III maupun di internal Universitas ABC. Berdasarkan hasil analisis data, ditemukan bahwa program studi teknik yang menjadi minat masyarakat kini adalah program studi teknik yang memiliki social senses, diantaranya Teknik Arsitektur, PWK dan Desain Produk. Sejalan dengan teori 4 (empat) unsur dibalik popularitas ketokohan seseorang, hal tersebut didasari akan trend calon mahasiswa terhadap daya tarik ilmu sosial yang bisa menemukan problem solving, kesuksesan public figure, dan industry branding. Upaya meningkatkan jumlah peminat program studi teknik, dapat dilakukan lewat kegiatan workshop dosen keilmuan kepada calon mahasiswa secara langsung serta open house universitas.
\end{abstract}

Kata kunci: kuliah, minat, strategi, teknik

\begin{abstract}
Title: Workshop to Increase the Number of Students at Engineering Study Program

Interest of prospective students toward engineering courses both in public and private universities keep decreasing. Data shows that only $14 \%$ of students choose engineering courses. In smaller scale, in one private university, students interest taking the engineering course are only $25 \%$ compared to student interest on taking the social courses. Purpose of this research was to conclude the reasons why student's interest toward engineering courses are low, and to comprise some proven solutions, related theories, in order to help solving the problems. Method used in this research is descriptive quantitative. Data used comes from new student's quisionaire, and related data with student's number studying engineering course in Kopertis III and in the internal of ABC University. Data analysis showed that current engineering courses which have more students, are engineering courses with social senses such as Architecture, Regional Planning, and Design Product. Along with the theory of 4 (four) aspecs behind the popularity of a figure, all caused by the current trend of prospective student's interest towards the social study attractiveness which leads to problem soving, the existence of success's public figures, and industry branding. Direct workshop between lecturer and prospective
\end{abstract}


students, and doing open house in the university could be strategies to increase the numbers of prospective student who want to take engineering course.

Keywords: lecture, interest, strategy, technique

\section{Pendahuluan}

Penelitian ini dilatarbelakangi oleh semakin terbatasnya lulusan sarjana teknik di Indonesia akibat rendahnya minat calon mahasiswa untuk mengambil program studi teknik. Dengan semakin berkurangnya lulusan maka sumber daya manusia terampil di industri terkait di Indonesia juga akan semakin terbatas. Hal ini amat disayangkan mengingat semakin homogen peminatan calon mahasiswa terhadap program studi tertentu, semakin kecil pula peluang lowongan pekerjaan setelah lulus nanti, yang akan mengakibatkan tingginya angka pengangguran. Berdasarkan data dari Forlap Dikti 2017 untuk semua unit perguruan tinggi, jumlah mahasiswa program studi teknik aktif adalah 893.663 mahasiswa, dan jumlah mahasiswa program studi sosial adalah 4.143.641 mahasiswa. Angka ini membuktikan bahwa mahasiswa aktif di program studi teknik hanya sebesar $18 \%$ dari seluruh jumlah mahasiswa yang aktif.

Berdasarkan data SBMPTN 2017 (seperti yang dikutip dari halaman youthmanual.com), tiga program studi yang paling diminati adalah Manajemen, Akutansi, dan Hukum, di mana ketiganya merupakan Fakultas Sosial dan Hukum. Salah satu contohnya adalah peminatan program studi teknik tahun 2017 di Universitas Indonesia, dimana hanya $14 \%$ yang ingin mengambil program studi teknik, 33\% ingin mengambil program studi sains dan 53\% ingin mengambil program studi sosial dan hukum. Hal yang tidak jauh berbeda juga terjadi pada universitas swasta. Berdasarkan data dari Kopertis III DKI Jakarta, pada salah satu universitas swasta dengan jumlah mahasiswa terbanyak pada tahun 2016 (46.677 mahasiswa), didapatkan data bahwa untuk mahasiswa S1 yang mengambil program studi teknik adalah sebesar $25 \%$, sedangan $75 \%$ mahasiswa mengambil program studi sosial.

Data di atas juga didukung oleh temuan dari hasil interaksi dengan para calon mahasiswa, yaitu murid SMA di beberapa sekolah yang sudah dilakukan melalui kegiatan workshop, seringkali muncul pertanyaan terkait tingkat kesulitan perkuliahan, apa sajakah pekerjaan yang dapat digeluti pada saat lulus nanti, dan apabila mereka lemah di beberapa mata kuliah tertentu apakah mereka bisa tetap masuk ke program studi tersebut. Hal ini tentunya menunjukkan adanya minat dari para calon mahasiswa walaupun sekaligus menunjukkan kurangnya pengetahuan dan adanya kekhawatiran mengenai sulitnya program studi teknik.

Dari paparan di atas dapat disimpulkan bahwa rendahnya peminatan calon mahasiswa terhadap program studi teknik terjadi di hampir semua universitas di Indonesia khususnya universitas di wilayah Kopertis III. Akan tetapi dari hasil uji interaksi dengan calon mahasiswa pada saat kegiatan workshop, didapat temuan bahwa 
sebenarnya masih banyak yang belum memiliki gambaran mengenai program studi teknik, baik secara umum maupun secara khusus. Tujuan dari dibuatnya penelitian ini adalah untuk memahami sudut pandang calon mahasiswa terhadap pemilihan program studi yang kemudian dapat digunakan untuk menyusun solusi-solusi aplikatif berlandaskan teori terkait dan hasil percobaan, yang sudah dilakukan dirasakan manfaatnya.

\section{Metode Penelitian}

Penelitian ini menggunakan metodologi deskriptif kuanitatif, yang bertujuan mendeskripsikan hasil temuan. Penelitian deskriptif ialah penelitian yang memberikan pemaparan tentang suatu fenomena (gejala), berdasarkan data, kemudia disajikan, dianalisis serta diintrepretasi (Narbuko \& Achmadi, 2003). Menurut Sugiyono (2013), metode penelitian kuantitatif, berasal dari filsafat positivisme, untuk menilai populasi atau sampel dengan teknik acak, pengumumpulan menggunakan instrumen penelitian, dengan analisis statistik.

Data yang digunakan berasal dari angka statistik yang didapatkan dari beberapa halaman website, angka statistik penerimaan mahasiswa per program studi di Fakultas Teknik Universitas $\mathrm{ABC}$, dan hasil rekap kuesioner yang dibagikan kepada mahasiswa baru Universitas ABC. Data-data yang ada kemudian diolah menjadi grafik dan dibuat analisa perbandingan.

Selain itu, juga terdapat tambahan data yang berasal dari diskusi secara terfokus yang dilakukan oleh tim peneliti pada beberapa SMA (Sekolah Menengah
Atas) berupa braindstorming (curah pendapat) tentang program studi teknik yang ada pada Universitas ABC. Diskusi terfokus berisikan tentang pengenalan program studi, prospek kerja, kurikulum dan durasi studi, serta forum tanya jawab. Data dari hasil diskusi kemudian digunakan sebagai pendukung untuk memverifikasi kebenaran dari data statistik yang ada.

\section{Hasil dan Pembahasan}

Peningkatan mutu pendidikan adalah salah satu faktor dalam meningkatkan kecerdasan bangsa. Salah satu aspek pendukung mutu pendidikan khususnya di perguruan tinggi adalah mahasiswa sebagai peserta didik, di mana dalam penelitian ini, kami lebih cenderung menganggap mahasiswa sebagai rekan belajar. Proses pembelajaran akan semakin efektif, apabila ada kesamaan minat antara dosen dan partnernya. Menurut Mc Donal dalam Hamalik (2001), motivasi timbul atas reaksi tujuan lewat feeling, yang dapat merubah energi seseorang.

Minat adalah proses yang cukup panjang yang dipengaruhi oleh faktor dari dalam diri maupun dari luar diri.

Terdapat dua aspek dalam mempengaruhi minat seseorang yaitu aspek kognitif dan afektif (Hurlock, 2007). Aspek kognitif diperoleh dari pengalaman pribadi dan faktor rumah, sekolah serta masyarakat. Faktor dari dalam diri dan lingkungan seseorang yang dapat memuaskan dirinya, maka akan memunculkan minat terhadap hal tersebut. Aspek Afektif lebih menekankan pada emosional pribadi, lebih pada preference syestem atau kelebih senangan seseorang. Apabila 
seseorang medapat pengalaman akan sesuatu yang menyenangkan, maka dapat meningkatkan minat, dan sebaliknya.

Usia siswa menjelang kuliah di Indonesia berada pada usia Remaja. Rata-rata usia lulusan SMA di Indonesia berada pada usia 16-18 tahun, sebesar 78,61 \% (Kemendikbud, 2016). Usia remaja sangat berkaitan erat dengan perubahan fisik dan psikis. Masa remaja pada usia belasan, merupakan usia pada kondisi yang tidak menyenangkan, dikarenakan terjadi banyak perubahan fisik, sosial, psikis, dan pada tahapan ini remaja cendrung pada proses pencarian identitas (Hurlock, 2007).

Remaja cenderung menyerap hal-hal yang ada disekitarnya, dan menjadikan pribadi seperti apa yang diserapnya. Pengambilan keputusan pada usia remaja, khusunya pemilihan program studi kuliah, tidak semestinya berasal dari orang tua. Desmita (2012) mengemukakan bahwa usia remaja merupakan tahapan rapprochment, dimana remaja menerima otoritas dari orangtua secara bersyarat. Terkadang terjadi penerimaan ataupun penolakan terhadap segala keputusan yang datang dari orang tua. Faktor tersebut merupakan salah satu pertimbangan remaja dalam menentukan program studi.

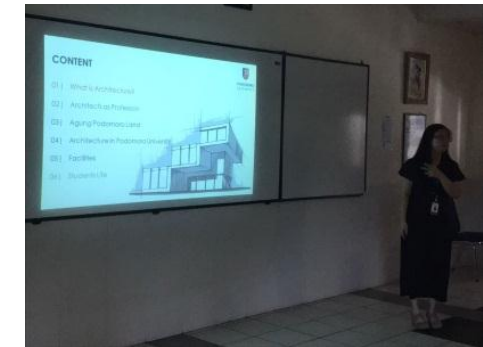

Gambar 1. Presentasi program studi teknik arsitektur di SMAK Penabur Jaya Bintaro
Mengacu kepada paparan teori di atas, diperlukan sebuah pengarahan yang baik dan benar sehingga proses pembentukkan pertimbangan dapat berjalan dengan lancar. Salah satu cara pemberian pengarahan adalah dengan pengenalan mengenai program studi atau bidang studi yang ada, langsung oleh dosen bidang keilmuan kepada para calon mahasiswa yang merupakan murid SMA. Dengan adanya pengenalan diharapkan agar calon mahasiswa dapat lebih memahami apa yang akan mereka pilih dan jalani nantinya, yang akhirnya akan membantu mereka untuk mempertimbangkan pilihan program studi yang akan mereka ambil.

Paparan di atas terverifikasi dengan hasil temuan kuesioner yang disebarkan kepada 39 responden mahasiswa baru Universitas ABC secara acak, yang dapat dilihat pada Grafik 1. Dari hasil temuan didapatkan data bahwa 59\% mahasiswa mengetahui keberadaan universitas maupun program studi yang ditawarkan melalui kunjungan dan presentasi ke sekolah.

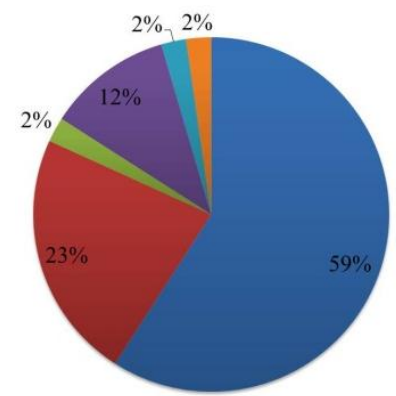

- Kunjungan ke Sekolah - Teman/ Saudara - Iklan TV/Radio - Website/ Sosial Media = Orang Tua

= Iklan lainnya

Grafik 1. Sumber informasi program studi dan universitas

Pada penelitian ini, yang sudah dilakukan pada saat kunjungan ke sekolah adalah kegiatan pameran pada acara-acara edufair di SMA-SMA, melakukan presentasi mengenai keilmuan di program studi teknik, 
sharing dari mahasiswa yang sudah menjalani perkuliahan, dan membuat workshop terkait keilmuan di sekolahsekolah.

Melihat peluang yang muncul dari kegiatan ke sekolah-sekolah untuk memberikan pemahaman sekaligus menarik minat calon mahasiswa untuk mengambil program studi tertentu, maka penelitian menggunakan strategi tersebut untuk meningkatkan jumlah calon mahasiswa untuk mengambil program studi teknik. Cara yang digunakan adalah dengan melibatkan dosen-dosen program studi teknik untuk acara-acara workshop dalam bentuk sosialisasi dan presentasi.

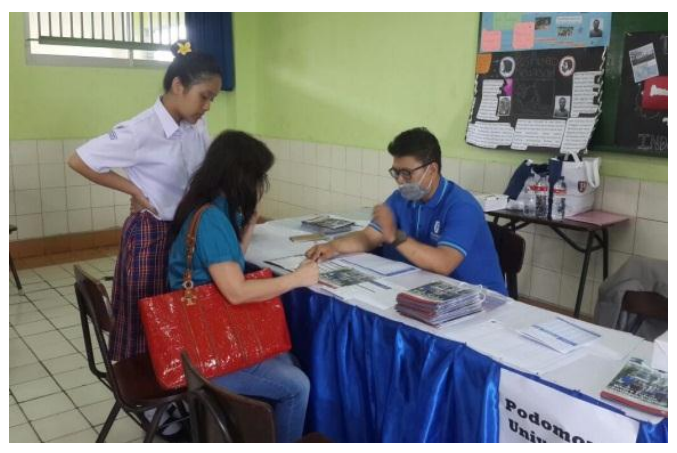

Gambar 2. Pameran pada salah satu edufair yang diadakan oleh SMA swasta di Bekasi

Data yang diterima dari marketing Universitas ABC (Grafik 2) menunjukkan bahwa tingkat aktivitas sosialisasi ke sekolah-sekolah yang sudah dilakukan meningkat cukup signifikan (rata-rata naik $15 \%$ per tahun) dari tahun 2014, tahun dimana universitas pertama kali berjalan. Hal ini mengakibatkan naiknya jumlah peminatan calon mahasiswa untuk berkuliah di Universitas ABC.

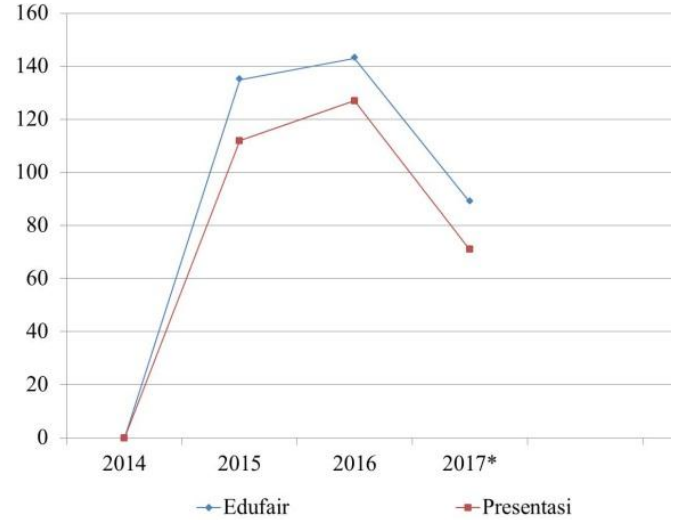

Grafik 2. Jumlah aktivitas sosialisasi ke sekolah SMA di Indonesia

Sumber: Data marketing $U A B C, 2017$

Sejalan dengan data di atas, jumlah mahasiswa yang ingin mendaftar dan bergabung ke program studi teknik di universitas juga semakin meningkat. Hal ini dapat dilihat pada Grafik 3 di bawah ini.

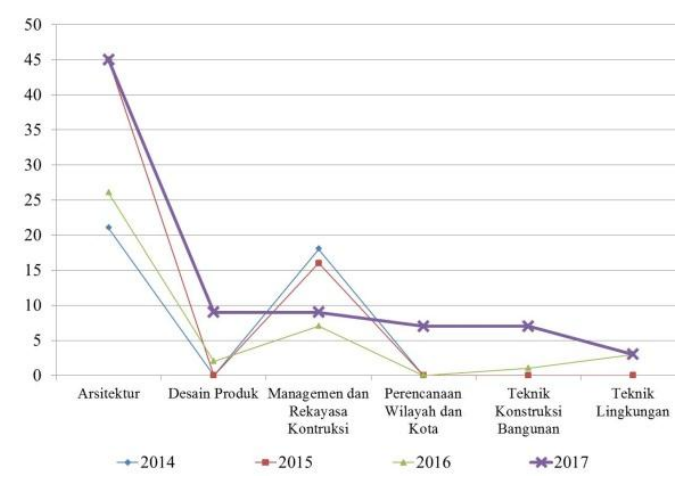

Grafik 3. Pertumbuhan jumlah mahasiswa teknik UABC

Sumber: Data marketing $U A B C, 2017$

*Data tahun 2017, berdasarkan aktivitas semester 1 yang sudah berjalan

Berdasarkan hasil diskusi dengan pihak marketing, juga didapatkan informasi bahwa aktivitas lain yang turut berperan serta adalah dengan melakukan open house universitas. Pada saat open house calon mahasiswa dapat mengunjungi universitas untuk melihat suasana dan kehidupan perkuliahan secara nyata. 


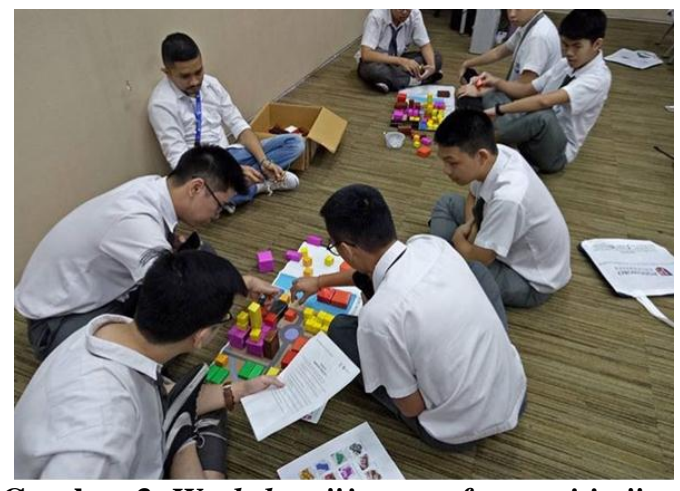

Gambar 3. Workshop "image of your cities" untuk program studi teknik perencanaan wilayah kota

Selain diajak berkeliling universitas, calon mahasiswa juga diundang untuk melakukan simulasi perkuliahan di mana mereka akan diberikan tugas kecil untuk diselesaikan sesuai dengan program studi yang mereka minati. Salah satu contohnya adalah workshop menyusun fungsi ruang kota yang dilakukan oleh Program Studi Teknik Perencanaan Wilayah Kota.

Penelitian kemudian dilanjutkan dengan melakukan analisa terhadap program studi teknik yang memiliki jumlah mahasiswa yang paling banyak. Tujuan dilakukannya analisa adalah untuk merumuskan aspek-aspek yang menjadi daya tarik program studi teknik tersebut sekaligus menganalisa pertimbangan yang digunakan oleh calon mahasiswa dalam memilih jurusan teknik tersebut.

Berdasarkan jumlah mahasiswa yang ada di wilayah Kopertis III DKI Jakarta. Jumlah mahaiswa Teknik, khususnya Program Studi Teknik Lingkungan, Sipil, Perencanaan Wilayah dan Kota, Arsitektur sebanyak 16.925 orang (Pangakal Data Kopertis III, diunggah November 2017). Dari Data Tersebut, Program Studi Teknik Arsitektur menempati jumlah tertinggi dibandingkan program studi lain.
Selengkapnya dapat dilihat pada Grafik 4.

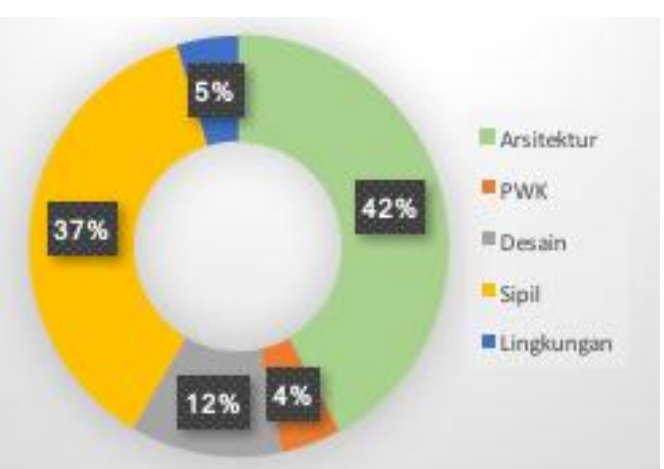

Grafik 4. Prosentase jumlah mahasiswa teknik pada wilayah Kopertis III tahun 2017 Sumber: data Kopertis III, 2017

Temuan ini juga terjadi di Universitas ABC, dimana untuk program studi teknik, mahasiswa Teknik Arsitektur menempati urutan pertama (dapat dilihat pada Grafik 5).

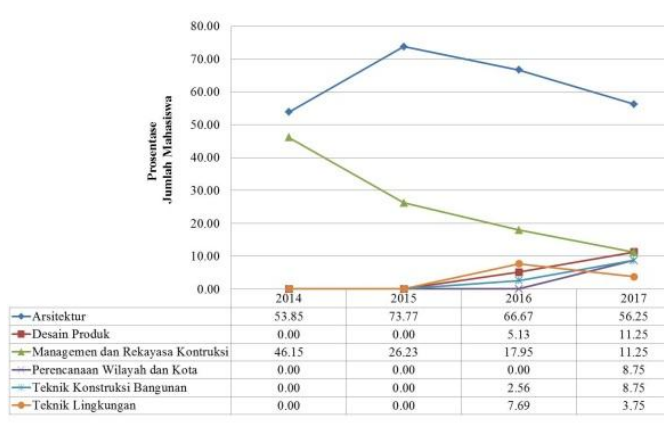

Grafik 5. Prosentasi jumlah mahasiswa teknik Universitas ABC

Sumber: data marketing UABC, 2017

Beberapa faktor diprediksi menjadi penyebab naiknya minat calon mahasiswa untuk kuliah di Program Studi Teknik Arsitektur. Dari hasil kuesioner mahasiswa baru Universitas $\mathrm{ABC}$, didapat beberapa jawaban terkait dengan apa yang diharapkan dari belajar di Program Studi Teknik Arsitektur. Jawaban yang paling dominan adalah keinginan untuk bekerja di bidang 
properti seiring dengan pesatnya perkembangan properti di Indonesia saat ini. Mereka mau kuliah di Universitas ABC karena latar belakang Perusahaan ABC yang mendukung universitas.

Sebagai salah satu pengembang properti terbesar di Indonesia, Perusahaan ABC sudah memiliki brand lebih dari 30 tahun dalam pengembangan properti. Menurut Siswanto (2004) brand image adalah presepsi masyarakat terhadap jati diri sebuah merek. Persepsi tersebut merujuk pada lembaga, ketokohan, maupun rekam jejak dari sebuah produk atau penawaran jasa.

Bukan hanya kepada brand image industri terkait, akan tetapi keberadaan tokoh poluler masyarakat dengan latar belakang pendidikkan akademik terkait juga turut mendorong masyarakat untuk mengambil Program Studi yang sama. Terdapat 4 (empat) unsur dibalik popularitas ketokohan seseorang yaitu; Visibility, Credibility, Attraction dan Power (Royan,2004). Visibility berkaitaan dengan jangkauan popularitas tokoh tersebut. Credibility berhubungan dengan product knowledge yang diketahui sang bintang, bisa berkaitan dengan latar belakang pendidikan, pengalaman, maupun keahlian. Attraction menitikberatkan pada daya tarik sang bintang. Power adalah kemampuan tokoh dalam menarik konsumen untuk membeli, bisa berkaitan juga degan jabatan yang dimilikinya, serta rekam jejak kesuksesan. Dalam hal ini, beberapa tokoh pemimpin seperti Ridwan Kamil (walikota Bandung) dan Tri Rismaharini (walikota Surabaya) menjadi tokoh-tokoh yang pantas untuk menjadi contoh dari tokoh masyarakat yang terlihat, mumpuni, terpercaya, dan menarik sebagai alumni dari Program Studi teknik arsitektur.

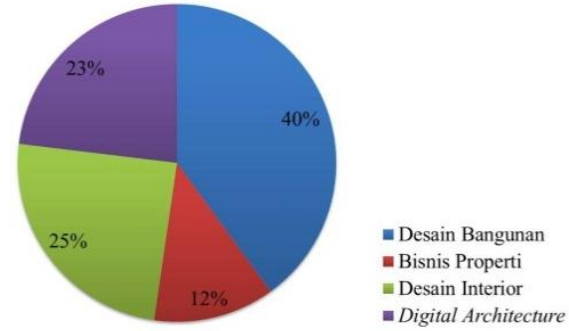

Grafik 6. Yang ingin dipelajari di program studi teknik arsitektur

Sumber: Kuesioner mahasiswa baru, 2017

Selain itu, mengingat adanya perkembangan kurikulum mengikuti perkembangan kebutuhan saat ini, di mana arsitektur juga mempelajari bidang keilmuan lainnya, maka ketertarikkan mahasiswa terhadap ilmu yang ingin mereka pelajari juga beragam. Hal ini dapat dilihat pada Grafik 6 di atas.

Dari hasil analisa terhadap peningkatan peminatan terhadap Program Studi Teknik Arsitektur, ada beberapa temuan tambahan yang dianggap menjadi faktor pendukung meningkatnya minat calon mahasiswa kuliah di Program Studi Teknik Arsitektur. Temuan tersebut adalah:

- Adanya perubahan persepsi calon mahasiswa mengenai Teknik Arsitektur setelah dilakukan presentasi bahwa pada saat ini Teknik Arsitektur bukan hanya mempelajari teknik murni dan gambar bangunan, akan tetapi juga mempelajari bidang keilmuankeilmuan lain yang terkait, seperti lingkungan, ekonomi, dan kota.

- Dalam studi kasus yang digunakan, peningkatan peminatan juga terjadi akibat nama besar dari Perusahaan ABC. Pada hasil rekap kuesioner mahasiswa baru, didapatkan temuan bahwa $48 \%$ mahasiswa memilih Universitas $\mathrm{ABC}$ karena nama 
Perusahaan $\mathrm{ABC}$ yang menjadi latar belakang Universitas ABC. Pada bagian alasan, banyak yang mengemukakan keinginan untuk bekerja di perusahaan tersebut setelah lulus nanti.

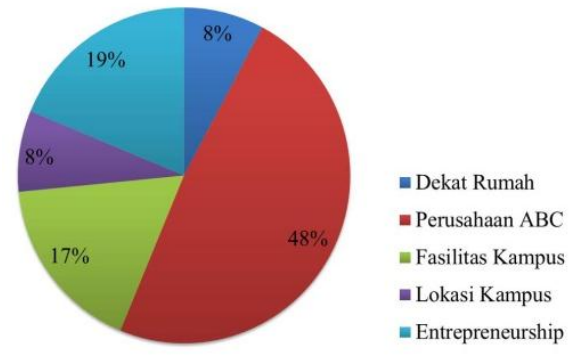

Grafik 7. Alasan memilih Universitas

Sumber: Kuesioner mahasiswa baru, 2017

- Keberadaan tokoh masyarakat yang berpengaruh dan merupakan lulusan dari program studi terkait juga dapat menjadi pendorong minat calon mahasiswa untuk kuliah di Program Studi yang sama.

\section{Kesimpulan}

Dari pemaparan di atas dapat disimpulkan bahwa kegiatan workshop, yang terdiri dari sosialisasi dan presentasi program studi teknik di sekolah-sekolah SMA dapat mendorong minat para calon mahasiswa untuk berkuliah di program studi teknik melalui pengarahan sudut pandang calon mahasiswa. Hal ini tergambar pada naiknya jumlah mahasiswa yang mengambil Program Studi Teknik di Universitas ABC.

Beberapa aktivitas yang sudah dilakukan pada saat workshop adalah presentasi, pengenalan kurikulum program studi teknik yang sudah mengikuti perkembangan jaman, diskusi terbuka, games yang beredukasi, dan pemutaran video yang terkait.

Selain kunjungan ke sekolah-sekolah, open house universitas juga dapat menjadi aktivitas tambahan pada kegiatan pengenalan universitas dan Program Studi.

Dari hasil penelitian juga didapatkan temuan tambahan bahwa branding industri terkait yang mendukung nama besar universitas dan tokoh populer di masyarakat juga turut menaikkan minat calon mahasiswa untuk mengambil program studi teknik di universitas tersebut.

\section{Daftar Pustaka}

Cholid Narbuko, Abu Achmadi. 2003. Metodologi Penelitian. Bumi Aksara. Jakarta.

Desmita. 2012. Psikologi Perkembangan Peserta Didik.Rosda.Bandung. Hamalik, Oemar. 2001. Kurikulum dan pembelajaran. Bumi Aksara. Jakarta.

Hurlock B.E. 2007. Psikologi Perkembangan Suatu Pendekatan Sepanjang Rentang Kehidupan. Penerbit Erlangga. Jakarta.

Royan, Frans. 2004. Marketing Celebrities. PT. Elex Media Komputindo. Jakarta.

Siswanto, Sutojo. 2004. Membangun

Citra Perusahaan. Damar Mulia Pustaka. Jakarta.

Sugiyono. 2013. Metode Penelitian Pendidikan Pendekatan Kuantitatif, Kualitatif, dan R\&D. Alfabeta. Bandung.

https://forlap.ristekdikti.go.id/mahasiswa

/homegraphbidang diakses pada 9 Januari 2018.

http://pddikti.kopertis3.or.id diakses pada 25 November 2017. 
https://www.youthmanual.com/post/duni a-sekolah/persiapan-kuliah/bedah10-program studi-yang-palingdiminati-di-sbmptn-2017 diakses pada 18 November 2017. https://sbmptn.ac.id/index.php?mid=14\& ptn=31 diakses pada 20 . 
Jurnal Teknik Arsitektur ARTEKS, Volume. 2, Nomor 2, Juni 2018 ISSN 2541-0598 